\title{
Stability of Human Immunodeficiency Virus 1 and 2 Antibody in Dried Blood Spot: A Pilot Study
}

\author{
Bhuvan Saud ${ }^{* 1}$, Sunita Masranggi ${ }^{1,2}$, Govinda Paudel ${ }^{1}$, Parmandand Bhandari ${ }^{2}$, Vikram Shrestha ${ }^{1}$ and \\ Gunaraj Dhungana ${ }^{1}$ \\ ${ }^{1}$ Department of Medical Laboratory Technology, Nepal \\ ${ }^{2}$ Sukraraj Tropical and Infectious Disease Hospital (STIDH), Nepal
}

*Corresponding author: Bhuvan Saud, Department of Medical Laboratory Technology, Janamaitri Foundation Institute of Health

Sciences (JFIHS), Hattiban, Lalitpur, Nepal

\section{ARTICLE INFO \\ Received: 湠 January 20, 2020}

Published: 仹 January 30, 2020

Citation: Bhuvan Saud, Sunita Masranggi, Govinda Paudel, Parmandand Bhandari, Vikram Shrestha, Gunaraj Dhungana. Stability of Human Immunodeficiency Virus 1 and 2 Antibody in Dried Blood Spot: A Pilot Study. Biomed J Sci \& Tech Res 25(1)-2020. BJSTR. MS.ID.004156.

\begin{abstract}
Dried Blood Spot (DBS) become a most proficient method of sample collection for both developed and developing countries. It is most commonly using to collect, store and transport sample for serological/immunological test, and pharmacokinetic studies, metabolic profiling etc. DBS has become an alternative tool for long-term storage, less hazardous and cost-effective method of sample handling. Thus, present study designed to investigate the stability of anti-HIV 1 and 2 antibodies in DBS in our environmental setting.
\end{abstract}

Abbreviations: HIV: Human Immunodeficiency Virus; DBS: Dried Blood Spot; STIDH: Sukra-Raj Tropical and Infectious Disease Hospital; NHRC: Nepal Health Research Council; COI: Cut of Index

\section{Short Communication}

Human Immunodeficiency Virus (HIV) infection appears as a global burden to public health. According to World Health Organization, in 2017Africa had the highest number of people living with HIV infection (25.7 million) and followed by SouthEast Asia (3.5 million) [1]. In Nepal the first case of HIV infection was diagnosed in 1988. Data in 2016 showed the prevalence of HIV infection among adult population in Nepal to be $0.17 \%$ [2] and as per data of The Joint United Nations Programme on HIV/ AIDS, in 2018 the incidence: prevalence and incidence: mortality ratio was reported to be 2.98 and 0.85 respectively [3]. For developing countries DBS has been established as an efficient technique for sample collection, transportation and storage. Due to its effectiveness, it is widely used to store, transport and handle samples in developed and developing countries. The use of Dried Blood Spot (DBS) may reduce the risks during transportation as well as occupational accidents. In developing countries, there are limited infrastructure and sophisticated laboratory setup, thus samples need to be sent to a higher laboratory for further investigation [4].
In such condition, DBS is the most appropriate method for storage and transportation of specimens. Therefore, we designed a pilot study to evaluate the stability of anti-HIV antibody in DBS at different temperature including room temperature, $4^{\circ} \mathrm{C}$ and $-20^{\circ} \mathrm{C}$ in our laboratory setting. Descriptive cross-sectional study was designed to conduct from April to October 2018. A total of 30 volunteer participants attending for Anti-Retro Viral Treatment at Sukra-Raj Tropical and Infectious Disease Hospital (STIDH), Teku were involved. Ethical approval was taken from the Nepal Health Research Council (NHRC), Ramshah Path, Kathmandu with registration number 353/2018. Witten consent was taken from all the volunteer participants. $5 \mathrm{ml}$ of venous blood sample was collected from patient in tubes without and with ethylenediaminetetraacetic acid anticoagulant tubes for anti-HIV 1 and 2 antibody detection and DBS preparation. Exact $75 \mu \mathrm{l}$ of ethylenediaminetetraacetic acid blood was transferred to the center of filter paper for DBS preparation and stored in different room temperature, $+4^{\circ} \mathrm{C}$ and $-20^{\circ} \mathrm{C}$ in triple layer plastic bag (Figure 1). 


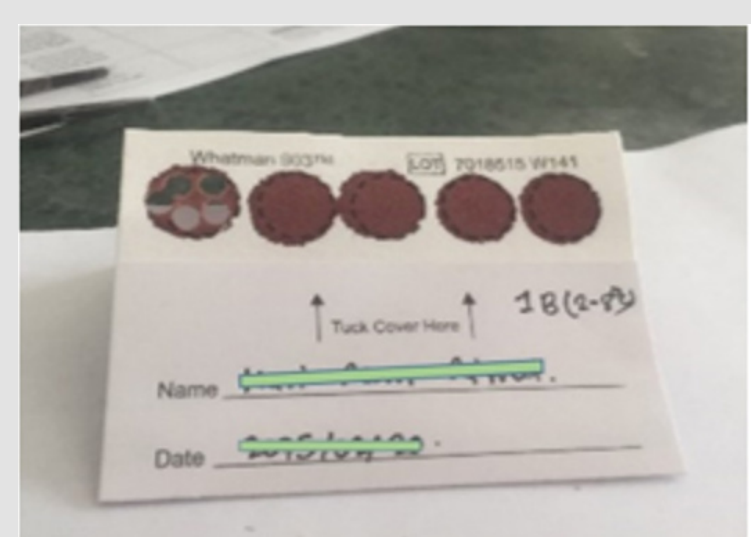

Figure 1: Whatman filter paper for dried blood spot preparation.

After 15 days 30 days, 60 days, 90 days interval DBS was punched with manual punching machine in an area that is fully saturated with blood and elution was performed by using $200 \mu \mathrm{l}$ phosphate buffer saline for overnight at room temperature. All the samples were tested by antibody to Human Immunodeficiency Virus type 1 and 2 by enzyme-linked immunosorbent assay (AUTOBIO, China) assay kit. The detected sensibility, specificity, negative predictive value and positive predictive value were all detected to be $100 \%$ in DBS testing under different temperature conditions and time periods. In this pilot study, there was no false positive or false negative result were observed. The Cut of Index (COI) of antibody after 90 days was similar to the COI observed in 15 days after storage in different environmental conditions. Various studies suggest that DBS can be used for serology/immunological testing, nucleic acid, metabolic, drugs and pharmacokinetic studies etc [4]. Yassin et al. showed that HIV antibodies in DBS stored in high temperature i.e. $45^{\circ} \mathrm{C}$ and $50^{\circ} \mathrm{C}$ are stable for 8 and 4 weeks respectively when tested by rapid diagnostic kit [5].

By using western blotting technique, antibody against HIV from DBS can be detected with high sensitivity and specificity [6]. Another study suggested that HIV positive samples showed positivity when stored at $4^{\circ} \mathrm{C}$ for 14 years [7]. In addition, DBS storage for six months in low temperature i.e. $4^{\circ} \mathrm{C},-20^{\circ} \mathrm{C}$ and $-70^{\circ} \mathrm{C}$ also showed a stability of HIV antibodies in when compared with initial concentration [8]. In DBS, HIV viral RNA and DNA stable for one year at $-20^{\circ} \mathrm{C}$, but at $30^{\circ} \mathrm{C}$ temperature viral RNA is less stable as compared with Proviral DNA [9]. Environmental condition directly affects the stability of antibody and nucleic acid of HIV. High temperature and humidity during shipment of DBS did not affect the HIV viral load [10]. DBS sample can be used as an alternative specimen with minimum biohazard risk and transmissible due to lose of infectivity of sample in filter paper matrix during drying [11]. Chemically pre-treated Whatman FTA filter paper increased the safety in handling, stable during shipment and long-term preservation of protein and nucleic acid of specimen. Thus, DBS is most the efficient method of long-term sample storage in ambient to $-20^{\circ} \mathrm{C}$ after 90 days with significant sensitivity and specificity. DBS has become an alternative tool for long-term storage of samples for developing countries. In addition, DBS requires a minimal invasive procedure, less hazardous, easy to transport and cost-effective method of sample handling.

\section{Acknowledgment}

We thank all study participants and laboratory staff of SukraRaj Tropical and Infectious Disease Hospital,Teku, Nepal.

\section{References}

1. (2017) WHO HIV data. People living with HIV by WHO region.

2. (2017) National HIV Testing and Treatment - Guidelines 2017. National Centre for AIDS and STD Control, Nepal.

3. (2018) USAID. Country factsheets. Nepal /2018. HIV and AIDS Estimates.

4. Saud B, Thapa B, Shrestha V (2018) Dried Blood Spot for Developing Countries. Curr Trends Biomedical Eng \& Biosci 14(3): 555886.

5. Yassin ME, Eldaif WA, Elkhider IM (2013) Evaluation of dry blood spot (DBS) stored at different temperature for detection of HIV antibodies by using different rapid tests. Surgery S12. 2: 2161-1076.

6. Castejon MJ, Yamashiro R, Oliveira CA, Veras MA (2017) Performance validation of western blot for anti-HIV antibody detection in blood samples collected on filter paper (DBS). Jornal Brasileiro de Patologia e Medicina Laboratorial 53(1): 5-12.

7. Williams D, Tookey P, Peckham CS, Cortina Borja M (2014) Long-term stability of HIV-1 antibody in dried blood spot samples and eluates. Aids 28(12): 1850-1851.

8. Castro AC, Borges LG, Souza RD, Grudzinski M, D Azevedo PA, et al. (2008) Evaluation of the human immunodeficiency virus type 1 and 2 antibodies detection in dried whole blood spots (DBS) samples. Revista do Instituto de Medicina Tropical de Sao Paulo 50(3): 151-156.

9. Aitken SC, Wallis CL, Stevens W, de Wit TR, Schuurman R, et al. (2015) Stability of HIV-1 nucleic acids in dried blood spot samples for HIV-1 drug resistance genotyping. PloS one 10(7): e0131541.

10. Thepbundit V, Ngo Giang Huong N, Salvadori N, Laolue A, Kunyanone N, et al. (2019) Feasibility of using dried blood spots for HIV viral load testing among HIV-infected individuals in Thailand using QIAGEN QIAsymphony-artus HIV-1 platform. J Med Virol 91: 1652-1659.

11.(2018) Control and Prevention, Shipping Guidelines for Dried-Blood Spot Specimens. Laboratory Quality Assurance and Standardization Programs. 


\section{ISSN: 2574-1241}

DOI: 10.26717/BJSTR.2020.25.004156

Bhuvan Saud. Biomed J Sci \& Tech Res

(C) This work is licensed under Creative

Submission Link: https://biomedres.us/submit-manuscript.php

$\begin{array}{ll}\text { BIOMEDICAL } & \text { Assets of Publishing with us } \\ \text { RESEARCHES } & \text { - Global archiving of articles } \\ \text { - Immediate, unrestricted online access } \\ \text { - Rigorous Peer Review Process }\end{array}$

